DOI: $10.15393 / j 9.2019 .6682$

УДК 821.161.1.09“1917/1992”

\author{
Ольга Юрьевна Юрьева \\ (Иркутск, Российская Федерация) \\ yuolyu@yandex.ru
}

\title{
Хронотоп повести В. Г. Распутина «Прощание с Матёрой»: этнопоэтический аспект
}

Аннотация. Анализ художественного своеобразия повести В. Г. Распутина «Прощание с Матёрой», впервые проведенный в аспекте этнопоэтики, позволяет по-новому взглянуть на организацию пространственновременных отношений в одном из самых известных произведений писателя, показать, как в пространственно-временных координатах и локусах повести воплощается сущность глобального конфликта эпохи: вечности и современности, культуры и цивилизации, природы и человека, добра и зла. Впервые хронотоп повести рассматривается как изображение национальной картины мира через конфликт сакрального и профанного пространств. Сакральный хронотоп представляет собой синтез природного и человеческого бытия и имеет соответствующие им координатные оси: по вертикали это «царский листвень» и церквушка, по горизонтали - Ангара и Матёра. В названии острова и деревни заложено несколько семантических значений: мать, мать-Земля, мать-Родина, матёрая, материк, духовный материк, крестьянская Атлантида. Матёра как часть национального Космо-Логоса представлена в мифопоэтическом ракурсе как живое, разумное, чувствующее существо, душой которого является зооморфный образ «Хозяина острова». Образ Ангары как важнейший горизонтальный сакральный топос, организующий хронотоп повести, вбирает в себя национальные архетипические коннотации реки-жизни, реки-дороги, реки-движения, обретает ярко выраженную символическую семантику времени, что связано с трагической коллизией наступления «последних времен». Организующий вертикальную ось хронотопа образ «царского лиственя» вбирает в себя черты архетипа мирового древа и национального тотема, символизирующего неуничтожимость вечной природы, кратковременность «пирровой победы» человека. Профанное пространство маркируется образами «нижнего», инфернального мира. Поэтика повести имеет ярко выраженный православный код, что придает финалу повести поистине апокалиптическое звучание.

Ключевые слова: Валентин Распутин, этнопоэтика, национальная картина мира, хронотоп, пространство, время, архетип, образ, сакральный, профанный

Об авторе: Юрьева Ольга Юрьевна - доктор филологических наук, профессор, зав. кафедрой филологии и методики, Иркутский государственный университет (664003, Российская Федерация, г. Иркутск, ул. К. Маркca, 1)

() О. Ю. Юрьева, 2019 
Дата поступления: 25.03.2019

Дата публикации: 28.06.2019

Для цитирования: Юрьева О. Ю. Хронотоп повести В. Г. Распутина «Прощание с Матёрой»: этнопоэтический аспект // Проблемы исторической поэтики. — 2019. - Т. 17. — № 2. - C. 289-313. DOI: 10.15393/j9.2019.6682

И

сследование творчества В. Г. Распутина в аспекте этнопоэтики обусловлено многими факторами. Главным из них является принцип национальной самоидентификации творческой личности. Этнопоэтический подход помогает определить «национальное своеобразие» русской литературы, ее «место в мировом художественном процессе», дать ответ, «что делает данную литературу национальной, в нашем случае - что делает русскую литературу русской» [Захаров, 1994: 9], позволяет выявить важнейшие закономерности и художественные особенности произведений Распутина. Настаивая на том, что национальная самоидентификация является опорой государственности, Распутин был «вынужден повторять»: мы «не считаем себя ни лучше, ни хуже их, мы другие. Мы и есть другие, слава Богу, и в этой инакости наше спасение» [Распутин, 2015: 984].

Эти слова напрямую перекликаются с мыслями Ф. М. Достоевского: «Мы убедились наконец, что мы тоже отдельная национальность, в высшей степени самобытная, и что наша задача - создать себе новую форму, нашу собственную, родную, взятую из почвы нашей, взятую из народного духа и из народных начал» ${ }^{.}$Но если Достоевский говорил о «почве» как «основе, основании, опоре» духовно-нравственной жизни страны, как обращении к народу, народной жизни, народной правде, национальной культуре, к действительности [Захаров, 2012: 17], то Распутин борется за ее сохранение и спасение. Писателя можно назвать продолжателем «почвеннических» традиций русской литературы. Не случайно такое значительное место в его публицистических статьях, выступлениях и интервью занимают идеи и образы Ф. М. Достоевского (см.: [Юрьева, 2007, 2012]).

Для Распутина, так же, как и для Достоевского, «почвенничество» было «его новым словом в истории идей», «почва» «все, что родит и роднит: народ, родина, родная речь, родная 
земля». «Быть почвенником» означало «любить Россию, народ, сознавать себя и быть русским, следовать вере отцов, чтить Отечество» [Захаров, 2012: 21-22].

Как верно отметил В. Н. Захаров, почвенником можно назвать Распутина еще и потому, что он сохранил «верность крестьянству и традиционным ценностям народной жизни, традициям русской словесности» [Захаров, 2012: 22]. Можно сказать, что почвенничество как основополагающая идея Распутина стало основанием эстетики и аксиологии его произведений. В статье «Мой манифест» писатель утверждал, что «у национальной литературы нет и не может быть другого выбора, как до конца служить той земле, которой она была взращена» [Распутин, 2007: 90]. Как заметил В. Курбатов, автор «Прощания с Матёрой» стал «предстателем за Сибирь, за ее характер, историю, за целостность ее облика» [Курбатов, 1991: 124]

Распутин мыслил себя русским писателем, в центре внимания которого - судьба России и русского народа, показанные через его «малую родину» и жизнь населяющих ее людей, а его писательское и человеческое призвание связано с долгом перед взрастившей его «малой родиной»: «Родину, как и родителей, не выбирают, она дается нам вместе с рождением и впитывается с детством. Для каждого из нас это центр Земли, независимо от того, большой ли это город или маленький поселок где-нибудь в тундре. С годами, становясь взрослей и обживая свою судьбу, мы присоединяем к этому центру все новые и новые края, можем сменить место жительства и переехать $<\ldots .>$, но центр по-прежнему там, на нашей “малой родине”. Её сменить нельзя» [Распутин, 2015: 495].

«Малая родина», полагал Распутин, дает человеку гораздо больше, чем он может осознать, и играет огромную роль в жизни, определяя «половину» его человеческих качеств, давая человеку первые и самые прочные «представления о добре и зле, о красоте и уродстве». Распутин считал, что человек становится художником лишь тогда, «когда свои собственные чувства он соединяет с общим народным и природным чувствилищем, в которых они, быть может, и проживают». Писатель чувствует себя носителем «родимых пятен», которыми отмечен его народ, и поэтому «черты малой родины, и дух ее» 
в творчестве писателя заметны всегда, ведь «малая родина это не только природа в деревне и история в городе, но еще и человеческие взаимоотношения, уклад жизни и традиции живущих. Это и язык, и вера, и определенные наклонности, вынесенные из самой земли вместе с ее солью» [Распутин, 2015: 496].

«Заданный» писателем этнопоэтический подход к творчеству позволяет «проследить этнокультурный компонент в самой художественной структуре, эстетическом строе произведений, в организации поэтического мира художника, его аксиологической системе» [Зырянов: 10].

Следует обратить внимание и еще на один немаловажный фактор, касающийся аксиологии национальной литературы. Как заметил В. Н. Захаров, письменность и литературу Древней Руси явило Крещение, что, по сути, и определило «концепцию, исключительное значение и высокий авторитет русской литературы в духовной жизни народа и государства», «дало идеал и предопределило содержание русской литературы», и потому «на протяжении последних десяти веков у нас была не столько литература, сколько христианская словесность», что и определяет национальное своеобразие русской литературь и культурь [Захаров, 1994: 6]. И. А. Есаулов так же полагает, что те особенности русской литературы и русской культуры, которые зачастую относят к разряду «национального своеобразия», сформированы «своеобразием православного образа мира, православного менталитета» [Есаулов, 1994b: 378-379]. Об этом же писал и Распутин в статье “"Откройте русскому человеку свет”. О Достоевском», полагавший, что «мощным стимулом для создания русского человека» стала православная вера и русская словесность. Последняя почти в течение ста лет «поддерживала духовное начало в народе, выполняла и священническую миссию», «продолжала духовное дело окормления и не позволила народу забыть молитвы» [Распутин, 2015: 580], стала «мерой глубины и состоятельности, прочности и талантливости народа» [Распутин, 1989: 140]. Русская литература веками питала «духовно-нравственное тело» народа, неся в себе главное: «...честь, совесть, все эти “не убий”, “не укради”, “не прелюбодействуй”, любовь в образе 
сладко поющей волшебной птицы, не разрушающей своего гнезда, а также и более нижние венцы фундамента — традиции и обычаи, язык и легенды, и совсем нижние - покойники и история» [Распутин, 2007: 209].

С одной стороны, литература как часть культуры - отражение процессов, которые происходят в общественной жизни и сознании; с другой - миссия ее состоит в сохранении национальной идентичности, в восстановлении национальных традиций и духовных ценностей. Литература понимается Распутиным как национальное явление, как воплощение души народа, способ его самовыражения, как «мера глубины и состоятельности, прочности и талантливости народа» [Распутин, 2015: 767]. Как замечает И. И. Плеханова, писатель всегда развивал и отстаивал одни идеи и ценности: «...совесть любовь - память - ответственность. И все это было помножено на проповедь веры и призыв к национальному самосознанию», а «цель его проповеди - защитить родное от клеветы и разрушения и вдохновить человека русской культуры на самосознание, открыв красоту и глубину национального чувства» [Плеханова: 308, 311].

Православный код определяет сущность творчества Распутина. «Материя души русского человека, - утверждал писатель, - должна быть русской и православной» [Распутин, 2015: 714].

Думается, в произведениях Распутина мы имеем дело с неким уникальным художественным синтезом, органично сплавляющим в единое целое оценочно- и злободневно-публицистический, религиозный, национальный (российский), этнологический (русский), геопоэтический (сибирский) и мифопоэтический (народный) стилевые пласты.

Особо хочется отметить лексический состав языка героев произведений Распутина, представляющего собой реалии ангарской вербальной культуры, одного из архаических вариантов русского языка, в котором наиболее полно сохранились черты традиционного диалекта и русской крестьянской цивилизации (см.: [Афанасьева-Медведева]), причем язык этот органично образует текст и придает повествованию особую достоверность и колорит. 
Творчество Распутина плотно впаяно в «сибирский текст» русской литературы не только потому, что все его произведения обращены к родному сибирскому краю, не только потому, что в них перед взором читателя развертываются величественные картины сибирского пейзажа, но и потому, что в них раскрывается душа сибиряка, являющегося не только представителем русского народа, но и выразителем особой, сибирской ментальности, сложившейся в определенных исторических, природных и климатических условиях, «русский в Сибири видоизменился в тип сибиряка, имеющего отличия и в психическом складе, и даже в физическом облике» [Распутин, 1994: 20]. Художественная интуиция писателя ведет его «вглубь сущности русского космоса, к самым основам национальной жизни, и не только национальной - вглубь природы человека, сущности мира в целом. Его интуиция - это умение услышать голос родовой памяти, многовековой памяти нации, и дать возможность услышать его читателю, узнать, распознать его в себе, в своем воспринимающем сознании, в глубинах своей души» [Галимова: 98].

Распутин был убежден: «Нет ничего в мире, что можно было бы поставить в один ряд с Сибирью. Кажется, она могла бы существовать как самостоятельная планета, в ней есть все, что должно быть на такой планете во всех трех царствах природы - на земле, под землей и в небе» [Распутин, 1994: 8]. Можно сказать, что в образе острова Матёра явлена художественная модель этой «самостоятельной планеты», живущей по своим, веками выработанным законам, предполагающим соборное бытие, неразрывную связь человека и природы, имеющую свои национально-архетипические пространственные локусы, определяющие не только материальные, но и духовные координаты этого планетарного пространства. Предлагаемый нами этнопоэтический ракурс исследования художественного хронотопа повести Распутина позволяет выявить главные, знаковые для русско-сибирской культуры пространственные и духовные локусы, в которых воплотился глобальный конфликт эпохи: вечности и времени, культуры и цивилизации, природы и человека, добра и зла.

Первые строки повести сразу как бы «задают» координаты пространственно-временного континуума повествования, его 
художественный хронотоп, не укладывающийся в рамки текущего, ощущаемого и видимого времени-пространства:

«И опять наступила весна, своя в своем нескончаемом ряду, но последняя для Матёры, для острова и деревни, носящих одно название» ${ }^{2}$.

Нескончаемый ряд времени, в котором так органично пребывала Матёра, для нее прерывается, а вечно приходящая весна становится «последней». Время одерживает победу над Вечностью, цивилизация побеждает культуру, смерть побеждает жизнь - так в первых строках повести определяется основной конфликт и трагический пафос повести, поистине библейский, апокалиптический масштаб происходящих в ней событий: «Скоро, скоро всему конец» (36).

Жизнь в Матёре «разорвалась пополам», и трещина прошла через сердца и судьбы людей. Гибель острова как части природного бытия обретает трагедийное звучание: она, как «подрубленное дерево», «откоренилась», как планета - «сошла с привычного хода» (6). Подчеркивая, что Матёра всегда жила «внутри» природных перемен, органично вписывалась в круговорот природной жизни, изображая ее неотъемлемой частью жизни природы и культуры, писатель показывает, что весь мир человеческий «сошел с привычного хода».

Сакрализация пространства в повести осуществляется в системе координат, организованной по вертикали «церквушкой», стоящей, как и положено, «на высоком чистом месте», хорошо видной «издали с той и другой протоки» (8), а по горизонтали - деревней Матёра с прилегающими к ней тайгой, кладбищем и поскотиной.

В судьбе матёринской церкви отразилась участь православия в атеистическом государстве:

«...церквушку эту в колхозную пору приспособили под склад. Правда, службу за неимением батюшки она потеряла еще раньше, но крест на возглавии оставался, и старухи по утрам слали ему поклоны. Потом и крест сбили» (8).

Но само присутствие церкви освящает пространство, придает особый смысл происходящим событиям, заставляет оглядываться на содеянное. 
В названии острова и поселка - Матёра - семантические пласты уходят вглубь национальной прапамяти. Фонетическое звучание названия острова вызывает в национальном сознании многочисленные смысловые ассоциации.

Матёра - это «мать» многим поколениям своих детей, в течение трех сотен лет сменявшим друг друга на этой земле. Это Мать-земля: тайга-кормилица, поскотина, огороды. Известно, что «мать-земля» в народном сознании сближается с архетипом Богородицы, Божьей Матери, а Россия, как замечал Распутин, «издавна верила в себя, как в Дом Богородицы, Богородица была покровительницей России, и все казавшиеся чудесными избавления от врагов и бедствий объяснялись ее заступничеством» [Распутин, 2007: 381]. Так возникает символическое обобщение: Матёра - это не просто остров и деревня, это часть России, в которой отражается ее судьба.

Звучит в названии деревни и определение «матёрая» - то есть старшая, сильная, главная. Матёра - часть великой страны, часть истории России и Сибири, отразившейся в ее судьбе: видела она бородатых казаков, ставивших на Ангаре Иркутский острог, стала свидетелем жестокого боя между войсками Колчака и партизанами, создавала «коммуниюколхоз». Как вся страна, Матёра послала своих сыновей защищать Родину в годы войны и, как многочисленные деревни по всей необъятной России, осиротела, не дождавшись многих из них. Так веками жила Матёра - внутри происходящих вокруг событий, в полном ладу с природой, включенная в круговорот мировой истории:

«Все это бывало много раз, и много раз Матёра была внутри происходящих в природе перемен, не отставая и не забегая вперед каждого дня» (6).

В конце концов Матёра - это целый «материк» для тех, кто родился и всю жизнь прожил на этой земле:

«И тихо, покойно лежал остров, тем паче родная, самой судьбой назначенная земля, что имела она четкие границы, сразу за которыми начиналась уже не твердь, а течь. Но от края до края, от берега до берега хватало в ней и раздолья, и богатства, и красоты, и дикости, и всякой твари по паре - всего, отделившись 
от материка, держала она в достатке - не потому ли и назвалась громким именем Матёра?» (34).

Библеизмы, включенные в описание острова, превращают его в некий «духовный материк», центр и ядро космоса народной жизни, с ее поверьями, традициями, праздниками и буднями, наполненными трудом и простыми человеческими радостями и скорбями. Как «Ноев ковчег», где «всякой твари по паре», Матёра когда-то дала жизнь поколениям людей и животных, спасала их в «лихие времена», а теперь сама обречена на уничтожение.

Образ Матёры ассоциируется с образом Атлантиды, и здесь обращает на себя внимание еще одно звуковое совпадение: родная деревня Распутина, ушедшая на дно рукотворного моря, называлась Аталанка. Матёра, как крестьянская Атлантида, уходит под воду, и вместе с ней гибнет русская крестьянская цивилизация. Сакрализуя уходящий мир Матёры, писатель показывает - это не просто географическое пространство, отделенное от всего остального мира водной преградой, это обетованная земля, святая земля предков.

Матёра представлена в повести как живое, разумное существо: она смотрит в сторону Ангары, потаённо лежит, набираясь соков раннего лета, и, как живое существо, предчувствует надвигающуюся на нее смертельную опасность:

«Обмирала Матёра от судьбы своей в эти часы: догорала заря за Ангарой, ярко обжигая глядящие в ту сторону окна; еще больше вытягивалась наверху бездна неба; ласково булькала под близким берегом вода. Догасал день и догасала, благодарствуя, жизнь округ: звуки и краски сливались в одно благостное дремотное качание $<. . .>$ и чувства человеческие в лад ему тоже сходились в одно зыбкое, ничего не выделяющее ответствие» (80).

Матёра в повести Распутина - часть национального Космо-Логоса, существующего в органическом единстве мира природы и жизни человека, что явлено в широком спектре мифологических образов, организующих национальную картину мира в повести.

Погружаясь в глубины национального духа и сознания, Распутин оживляет древние мифопоэтические представления о мире, подчеркивая тем самым «со-природность» человеческого бытия, 
установившегося в Матёре, расширяя границы материального мира до бесконечности:

«И казалось, сдвигались плотней в деревне избы и, покачиваясь, тянули единый, под ветер, нутряной голос; казалось, наносило откуда-то запахом старых, давно отлетевших дымов; казалось, близко подступало все, что было на острову, и, стоя друг за другом, рукотворное и самотворное, выглядывая друг из-за друга, единым шепотом что-то спрашивало. Что? - не понять, не услышать было, но мнилось, что и на это, невнятное и неслышимое, следует отвечать» (80).

В этой жизни есть место не только плоской реальности, но и тем древним, пришедшим из мифологических представлений человека о мире существам, каковым является «ни на кого не похожий зверек», о котором Распутин пишет как о живущем на острове реальном существе:

«А когда настала ночь и уснула Матёра, из-под берега на мельничной протоке выскочил маленький, чуть больше кошки, ни на какого другого зверя не похожий зверек - хозяин острова. Если в избах есть домовые, то на острове должен быть и хозяин» (43).

Как замечает Т. Л. Рыбальченко, в зооморфном образе Хозяина острова автор персонифицирует одушевленность природного мира, «акцентируя, что он не плод воображения персонажей, а объективное проявление бытия, нематериальная сущность некоего земного локуса, дух острова, не творец, а порождение всех проявлений жизни на острове» [Рыбальченко: 10]:

«Никто никогда его не видел, не встречал, а он здесь знал всех и знал все, что происходило из конца в конец и из края в край на этой отдельной, водой окруженной и из воды поднявшейся земле. На то он и был Хозяин, чтобы все видеть, все знать и ничему не мешать. Только так еще и можно было остаться Хозяином чтобы никто его не встречал, никто о его существовании не подозревал» (43).

Единая с Матёрой судьба Хозяина острова усиливает апокалиптические мотивы повести:

«И хоть предчувствовал Хозяин, что скоро одним разом все изменится настолько, что ему не быть Хозяином, не быть и вовсе 
ничем, он с этим смирился. Чему быть, того не миновать. Еще и потому он смирился, что после него здесь не будет никакого хозяина, не над чем станет хозяйничать. Он последний. Но пока остров стоит, Хозяин здесь он» (44).

В одном из своих очерков («Откуда есть-пошли мои книги») Распутин писал о своем необычном герое: «Я так и уехал из деревни, не встретив ни домового, ни лешего, ни баннушки, ни русалки, но, когда писал “Прощание с Матерой”, не мог обойтись без хозяина острова. Это не дань язычеству, а дань поэзии, без которой не жил народ. Да и, признаться, я продолжаю верить, что, вопреки полной просвеченности мира, должны существовать следующие их глубокой древности земные наши хранители» [Распутин, 2007: 507].

Хозяин острова - древний хранитель Матёры, воплощение ее души, мудрой и всечувствующей.

Сакральный мир организован по законам природного естества, одухотворенного верой, трудом и традициями. Здесь все имеет свою душу, все пронизано единым соборным бытием, центром которого является «изба» - родовое гнездо. В мифологических представлениях славян изба - это центр мира, центр космоса крестьянской жизни. Изба дает прибежище от холодов и жизненных невзгод, она собирает и хранит семью. Изба - живое существо, живущее одним бытием с человеком. Потому Дарья «соборует», «обряжает» свою избу перед тем, как «пожогщики» предадут ее огню, провожает ее, как провожают покойника: белит, моет, украшает пихтой, от которой «тотчас повеяло печальным курением последнего прощания, вспомнились горящие свечи, сладкое заунывное пение. И вся изба сразу приняла скорбный и отрешенный, застывший лик. “Чует, ох чует, куда я ее обряжаю”, - думала Дарья, оглядываясь вокруг со страхом и смирением: что еще? что она выпустила, забыла?» (157).

Сакральное пространство объединяет мир человеческий и мир природный, и каждый из них имеет свою систему планов, координат и локусов. План природной жизни организован по вертикали величественным «царским лиственем», а по горизонтали - Ангарой. 
Образ Ангары - важнейший сакральный топос, формирующий хронотоп повести. Сакрально-мирообразующая функция образа Ангары в «Прощании с Матёрой» имеет глубокую личностную окраску. Распутин признавался: «Я, например, когда я испытываю нечто вроде молитвы, то вижу себя на берегу старой Ангары, которой теперь нет, возле моей родной Аталанки, острова напротив и заходящее за другой берег солнце. Немало в жизни повидал я всяких красот, рукотворных и нерукотворных, но и умирать буду с этой картиной, дороже и ближе которой для меня ничего нет. Я верю, что и в моем писательском деле она сыграла не последнюю роль: когда-то в неотмеченную минуту вышел я к Ангаре и обомлел - от вошедшей в меня красоты обомлел, от явившегося из нее сознательного и материального чувства родины» [Распутин, 2015: 496].

Ангара связывает два мира: «свою Матёру» и «чужие берега». Была «своя Ангара», прилегающая к «островной земле», и была «большая Ангара», «освобожденно открывающаяся», вытягивающаяся в «могучую сверкающую течь» (6), по которой шли пароходы, приезжали чужие люди, угадывалась другая жизнь. Река-жизнь, река-дорога, река-движение - все эти мифопоэтические смысловые нюансы национального архетипа реки воплощены в образе Ангары.

В своем течении Ангара преодолевает земные берега и сливается с рекой небесной. Река «противопоставляется безблагодатной сухости», связывается в мифопоэтическом сознании с архитепическим национальным мотивом крещения, переносит благодать мира горнего в мир земной, эмпирический [Есаулов, 1994а: 37].

Прослеживается в образе Ангары и материнский архетип, что весьма свойственно для национального сознания: широкая, могучая, богатая рыбой, она кормила, поила, помогала матёринцам в самые трудные времена. Распутин показывает, как река участвует в круговороте жизни тех, кто населяет ее берега, как, часто того не подозревая, ангарцы поклоняются ей, относятся к ней, как говорил Распутин, «как к той живой и неизменной вечной связи, которая соединяет все поколения, и прошлые, и будущие» [Распутин, 1984: 33]. В повести Ангара 
обретает ярко выраженную символическую семантику материально выраженного течения времени, что связано с трагической коллизией наступления «последних времен»: «...течет Ангара, и течет время». Ангара обретает коннотативные признаки границы, «водораздела» между двумя мирами - caкральным и профанным, истинным и ложным, традиционным и новым: переправляющийся через Ангару на остров Павел «всякий раз поражался тому, с какой готовностью смыкалось вслед за ним время: будто не было никакого нового поселка, откуда он только что приплыл, будто никуда он из Матёры не отлучался», «приплывал - и невидимая дверка за спиной захлопывалась» $(65,66)$.

Ангара является одним из главных образов-персонажей повествования: со своим внешним обликом, норовом, особой ролью в жизни людей и со своей судьбой, когда-то полной красоты и величия, а ныне - гибельной и трагической (см.: [Имихелова]). Ведь пройдет немного времени и, как с горечью пишет Распутин в очерке «Откуда есть-пошли мои книги», не станет Ангары, «молодой, быстрой и завораживающей, в которую я беспрестанно заглядывался в детстве. Теперь она, обузданная плотинами, изъезженная, распухшая, гнилая, лежит в беспамятстве, теряя свое имя. Надо ли гордиться, что я, кажется, последним пропел ей сыновью песню со словами, которые она в меня наплескала?!» [Распутин, 2007: 504]. Г. В. Афанасьева-Медведева замечает: «Образ Ангары в произведениях В. Г. Распутина становится символом духовнонравственных ценностей, чистоты, святости, Родины и вместе с тем символом их безвозвратной утраты» [Афанасьева-Медведева: 28].

Вертикальная ось этого природного сакрального мира царский листвень:

«Матеру, и остров и деревню, нельзя было представить без этой лиственницы на поскотине. Она возвышалась и возглавлялась среди всего остального, как пастух возглавляется среди овечьего стада, которое разбрелось по пастбищу. Она и напоминала пастуха, несущего древнюю сторожевую службу. Но говорить “она” об этом дереве никто, пускай пять раз грамотный, не решался; нет, это был он, “царский листвень” - так вечно, 
могуче и властно стоял он на бугре в полверсте от деревни, заметный почти отовсюду и знаемый всеми» (145).

Царский листвень, являясь воплощением традиционного архетипа мирового древа, становится вертикальной осью сакрального мира острова и находится в таинственных отношениях с миром иным:

«И так, видно, вознесся он, такую набрал силу, что решено было в небесах для общего порядка и размера окоротить его - тогда и грянула та знаменитая гроза, в которую срезало молнией “царскому лиственю” верхушку и кинуло ее на землю» (145).

Корнями же своими царский листвень, как гласит поверье, сложившееся в стародавние времена, «крепит» остров «к речному дну, одной общей земле». Матёринцы верили: «...покуда стоять будет он, будет стоять и Матёра» (145).

Царский листвень выполняет роль традиционного для славянских племен «наглавного, державного» тотемного дерева, к которому люди испытывали «почтение и страх», в Пасху и Троицу «задабривали его угощением, которое горкой складывали у корня» (145). Желание «пожогщиков» уничтожить листвень обретает символические черты борьбы природы и человека, выражает идею несокрушимости природы и тщетности попыток жалкого человека победить вечность. Антропоморфные характеристики лиственя перемещают, казалось бы, обычный «технический» процесс в онтологическую сферу: Распутин представляет трагическую по своему накалу картину схватки между миром сакральным и миром профанным, миром времени и миром вечности, культуры и цивилизации. Как непокорного «еретика», люди решили сжечь царский листвень, но «огонь поплясал, поплясал и начал, слизнув бензин, сползать, отделяться от дерева, точно пылал вокруг воздух, а листвень под какой-то надежной защитной броней оставался невредимым. <..> Мужики ругались. А дерево спокойно и величественно возвышалось над ними, не признавая никакой силы, кроме своей собственной» (149).

Попытка спилить царский листвень тоже обернулась неудачей. Орудие цивилизации - бензопила, только «дрыгнула», «зашлась высоким натужным воем», но смогла оставить на 
стволе лишь «легонький надрез». И люди сдались. А листвень, «неповалимый», «могучий и норовистый», «не поддавшийся людям», оставаясь последним оплотом сакрального мира, «строго и внимательно смотрел на нижний край острова, где стояли матёринские леса. Теперь их там не было» и «один выстоявший, непокорный» царский листвень «продолжал властвовать надо всем вокруг. Но вокруг него было пусто» $(150,151)$.

Трагизм ситуации состоит в том, что бесспорная победа лиственя временна: несокрушенный, выстоявший в схватке, он вместе с островом в скором времени уйдет под воду. Но в этой коллизии кроется особый смысл: с одной стороны, листвень, как капитан тонущего корабля, уйдет вместе с островом, с другой, его несокрушимость - это символ неуничтожимости вечной природы, победу над которой так опрометчиво празднует человек, не разумеющий, что не в его силах уничтожить природу, что все нанесенные ей обиды и утраты сторицей вернутся и обернутся для человека страшной бедой самоуничтожения.

Есть и еще один семантический нюанс в образе царского лиственя. Настаивая на праве «национальной собственности на культуру», Распутин напоминает: «В древности на Руси наказывали: “Помяните одно: только коренью основанье крепко, то и древо неподвижно; только коренья не будет к чему прилепиться?!” [Распутин, 2015: 773]. Так «царский листвень» становится символом национальной русской культуры и самобытности, а в его неподатливости и устойчивости - залог спасения страны и народа. Упадет листвень, рухнет культурная подпора, и погибнет народ, ибо разрушение культуры является для Распутина одной из трех (наряду с ядерной и экологической) опасностью «уничтожения человечества» [Распутин, 2015: 775].

Сакральное пространство с центром-Матёрой противостоит наступающему на него пространству профанному, центром которого становится безымянный поселок. В этом столкновении реализуется конфликт Вечности и Времени, культуры и цивилизации, природы и человека, жизни и смерти, добра и зла. Профанное пространство маркируется образами, связанными с миром «нижним», инфернальным. Как 
знаки запустения и смерти, «гуще и нахальней полезла крапива», «мертво застыли окна в опустевших избах», как к покойнику, «растворились ворота во дворы». Появляется образ «нечистой силы», которая с хозяйской уверенностью открывала ворота, «чтоб сильнее сквозило, скрипело да хлопало», накладывая на все печать неминуемой погибели (6-7).

Чужой и чуждый мир вторгается в размеренную, веками установившуюся жизнь матёринцев, покушается на самые сокровенные святыни. Пришельцы разоряют деревенский погост, «мертвых грабют», покушаясь на самое святое: на память о предках, на таинственный, табуированный для вторжения мир мертвых. Матёринцы называют пришлых рабочих «чертями», «нехристями», «нечистой силой», «аспидами ненасытными» («аспидом» сибиряки называли коварного, хитрого, злобного человека, богоотступника, богохульника [Афанасьева-Медведева: 44]). Даже в непонятном для стариков слове «санэпидстанция» слышится им подтверждение сатанинской сущности новых явлений:

«- Какой ишо сам-аспид-стансыи? <..> Над старухами измываться! Сам ты аспид! <..> Кары на вас нету» (18).

В повести возникает противостояние двух сил, двух миров, представляющих мир сакральный и мир профанный, мир Вечности и мир Времени: пришельцы, чужаки, «нехристи», «официальные лица» и - матёринские жители, старики и старухи, «граждане затопляемые». Возмущенные святотатством пришельцев, матёринцы отказывают им даже в звании человека, настаивая на их поистине бесовском происхождении:

«Не было у тебя, у поганца, отца с матерью. Ты не человек. У какого человека духу хватит?!» (17).

Представители двух миров не только исповедуют совершенно разные взгляды на жизнь, придерживаются совершенно противоположных ценностей, они даже говорят на разных языках, не слыша и не понимая друг друга. Пытаясь утихомирить разбушевавшихся матёринских старух, «официальное лицо» «товарищ Жук» произносит, обращаясь к «гражданам затопляемым»: 
«- Товарищи! Тут с вашей стороны непонимание. Есть специальное постановление, - знал Жук силу таких слов, как "решение, постановление, установка", хоть и произнесенных ласково, - есть специальное постановление о санитарной очистке всего ложа водохранилища. А также кладбищ... Прежде чем пускать воду, следует навести в зоне затопления порядок, подготовить территорию...» (20-21).

Да и как могут понимать матёринцы слова Жука, если их родная земля, на которой они родились и выросли, в которой упокоились их предки, для него лишь «зона затопления», «территория», «ложе водохранилища». Сущность подобных людей очень точно определил дед Егор:

«Тебе один хрен, где жить - у нас или ишо где. А я родился в Матёре. И отец мой родился в Матёре. И дед. Я тутака хозяин. И покулева я тутака, ты надо мной не крыль. <...> И меня не зори. Дай мне дожить без позору» (22).

«Позором» называет дед Егор и происходящее разорение его земли, а также то, что, прикрываясь интересами народа, нуждами страны, государства, творят на его земле чужаки.

Возникает в повести еще одна бинарная оппозиция образов: «хозяин / временщик-турист». Представлен таинственный Хозяин острова, хозяином называет себя дед Егор, хозяйкой своей земли ощущает себя старуха Дарья. Но на роль хозяев претендуют и другие. Товарищ Жук обращается к возмущенным матёринцам:

«- Вы знаете, на этом месте разольется море, пойдут большие пароходы, поедут люди... Туристы и интуристы поедут. А тут плавают ваши кресты. <...> Приходится думать и об этом...

- А о нас вы подумали? - закричала Вера Носарева. - Мы живые люди, мы пока здесь живем. Вы загодя о туристах думаете...» (21).

А поднявшему на народ голос председателю сельсовета Воронцову дед Егор отвечает:

«- Ты сам тутака без году неделя. Сам турист... ране моря только причапал» (21-22).

В творчестве Распутина возникает тип «туриста», временщика, для которого нет ничего святого. Он живет одним днем, 
и интерес для него представляет лишь то, что принесет сиюминутную выгоду. Он не думает о будущем, о том, что на этой разоренной им земле будут жить его дети и внуки. В оппозиции «хозяин / временщик» реализуется мысль Распутина о происходящей в сознании современников трагической девальвации, подмене нравственных понятий, определяющих отношение человека к своей земле, к родному дому, к «малой родине». В этой оппозиции также реализуется конфликт Природы и человека, культуры и цивилизации, когда стремление к сиюминутной наживе, к комфорту, к легкой жизни оборачивается в будущем глобальной катастрофой. Такими временщиками являются не только пришлые чужаки, но и свои, матёринские жители, такие как Клавка Стригунова, Петруха, получающий деньги за пожог домов; Соня, мечтающая о городской комфортной жизни; внук Дарьи Андрей, обидевший ее тем, что, уехав, даже не простился с Матёрой. Все они оторвались от родных корней, погнались за легкой жизнью, забыв о высокой плате за предательство - плате пустотой жизни, бессмыслицей существования, разорением родной земли, которая вот-вот станет непригодной для существования.

Такого человека жалеет Дарья, удивляя этой жалостью внука:

«- Ты говоришь: почто жалко его? А как не жалко? Ежли на гонор не смотреть - родился ребятенком и во всю жисть ребятенком же и остался. <...> Ни власти над собой, ни холеры. А сколь на его всякого направлено - страшно смотреть. И вот он мечется, мечется... По-пустому же боле того и мечется. Где можно шагом продти, он бежит. А ишо смерть... Как он ее, христовенький, боится! За одно за это его надо пожалеть. Никто в свете так не боится смерти, как он. Хужей всякого зайца. А от страху чего не наделаешь...» (108-109).

«От страху» перед небытием человек старается утвердить свою власть над Вечностью, над Природой. Из страха поддается он на сатанинские соблазны, разрушая все вокруг себя, ища легкой жизни, от которой предостерегает своего внука Дарья:

«Прощай и ты, Андрей. Прощай. Не дай Господь, чтобы жизнь твоя показалась тебе легкой» (114). 
Мудрая старуха понимает, что ничто так не развращает человека, как легкие деньги, легкая жизнь, за которые потом приходится тяжко расплачиваться.

Сакральный мир Матёры, как и положено, «стоит» на праведниках, представленных в повести образами стариков и старух. В центре - Дарья и Богодул, представляющие две стороны русского характера - «деятельную и волевую». Как полагал Распутин, в этом «двуединстве» заложены основания перехода «к другого рода деятельности - духовной». Именно духовная деятельность «выпестовала нашу православную душу и воздвигла ее на высоту, с которой дароносит лучшая в мире культура. В ней-то, должно быть, и обитает то знаменитое женское начало, которое, склонны относить к России как единственное. Нет, другая сторона русской сущности мужеская, производящая способность к сверхъестественным деяниям. А вместе они и составляют то плодотворное лоно нашего духа, в котором не прекращается вынашивание» .

Несомненно, образ Дарьи восходит к архетипу «мудрой старухи», но главное в нем - национальное начало. Хранительница сакрального пространства Дарья - наследница тех истинных русских женщин, для которых «конституцией было Евангелие, а социальная справедливость заключалась в понятиях “по-Божески” или “не по-Божески”» [Распутин, 2007: 382]. Именно в Дарье отразились «отзвуки и отсветы Богородичности», которые, по мнению писателя, «должны являться всякой женщине» [Распутин, 2007: 375]. О сущности представленных в повести характерах В. Курбатов писал: «Это русский человек в его стоянии, в его прощально открывшемся мужестве и терпении, в его женской, материнской стихии» [Курбатов, 2000: 3].

Распутин словно выполнил завет почитаемого им Достоевского, сетовавшего на то, что «русские писатели только и знают, что обличать всяких уродов и ставить Россию к позорному столбу» и недоумевавшего, «почему у них, у писателей, ни у кого не хватило смелости показать во весь рост русского человека, которому можно было бы поклониться?» [Распутин, 2015: 855]. Созданные Распутиным образы из народа, воплотившие свойства национального сознания и духа, тяготеют 
к «иконическим эмблемам» русского национального характера: Настена из «Живи и помни», старуха Анна из «Последнего срока», Дарья из «Прощания с Матёрой».

Выстроенная в повести система образов и мотивов демонстрирует существующую «до недавнего времени на Ангаре (до затопления) систему морали, в основе которой лежали нравственные правила человеческой жизни, отзывчивость, сердечность, чуткость к чужому горю, сострадание, способность к активному сопереживанию, милосердие, миролюбие, отражающие установку на понимание и приятие "другого", все эти национальные ценности, по сути, гармонизировали и духовно укрепляли крестьянский мир ангарцев, и, в конечном итоге, обеспечивали им выживание» [Афанасьева-Медведева: 26].

Истинным трагизмом наполнены заключительные сцены повести. На Матёру пал туман, скрывший привычные очертания острова, стерший грань между водой и сушей, землей и небом: «Кругом были только вода и туман и ничего, кроме воды и тумана» (179). Исчезли границы между двумя мирами, и люди почувствовали, что находятся на границе, на переходе: между жизнью и смертью, Вечностью и Временем, бытием и инобытием, что перекликается со словами Апокалипсиса: «И небо скрылось, свившись как свиток; и всякая гора и остров двинулись с мест своих» (Откр. 6: 14). Очнувшиеся от сна в бараке Богодула старухи не могут понять, день или ночь, живые они или «неживые»:

«Уставились в окно и увидели, как в тусклом размытом мерцании проносятся мимо, точно при сильном вышнем движении, большие и лохматые, похожие на тучи очертания»;

«В раскрытую дверь, как из разверстой пустоты, понесло туман и послышался недалекий тоскливый вой - то был прощальный голос Хозяина. Тут же его точно смыло, и сильнее запестрило в окне, сильнее засвистел ветер, и откуда-то, будто споднизу, донесся слабый, едва угадывающийся шум мотора» (180).

Как отмечает Н. В. Ковтун, «туман - предвестие гибели, но в древней культуре и знак неведения, Распутин отдает судьбу земли в руки человека, повесть имеет открытый финал» [Ковтун: 157]. Мир жизни и мир смерти сливаются в единое 
целое, ибо в реальности разрушены как материальные, так и духовные основы, на которых держатся витальные силы жизни, а смерть представляется лишь как переход в тот мир, где все остается незыблемым и нетронутым человеческим безрассудством.

\section{Примечания}

1 Достоевский Ф. М. <Объявление о подписке на журнал «Время» на 1861 год> // Достоевский Ф. М. Полн. собр. соч.: в 30 т. Л.: Наука, 1978. Т. 18. С. 36.

2 Распутин В. Прощание с Матерой // Распутин В. Повести и рассказы. М.: Современник, 1985. С. 6. Далее ссылки на это издание приводятся в тексте статьи с указанием страницы в круглых скобках.

3 См. статью В. Г. Распутина «Сколько же мы будем еще запрягать?»: [Распутин, 2015: 856].

\section{Список литературы}

1. Афанасьева-Медведева Г. В. Народное слово в рассказах и повестях Валентина Распутина: словарь: в 2 т. - Иркутск, 2017. - Т. 1. - 432 с.

2. Галимова Е. Ш. Архетипический образ реки в художественном мире Валентина Распутина // Время и творчество Валентина Распутина: материалы Междунар. науч. конфер., посвящ. 75-летию со дня рождения Валентина Григорьевича Распутина. - Иркутск: Изд-во ИГУ, 2012. -C. 98-109.

3. Есаулов И. А. Категория соборности в русской литературе (к постановке проблемы) // Проблемы исторической поэтики. - Петрозаводск: Издво ПетрГУ, 1994. - Вып. 3. - С. 31-60 [Электронный ресурс]. - URL: http://poetica.pro/journal/article.php?id=2372 (10.03.2019). DOI: 10.15393/ j9.art.1994.2372 (a)

4. Есаулов И. А. Литературоведческая аксиология: опыт обоснования понятия // Проблемы исторической поэтики. - Петрозаводск: Изд-во ПетрГУ, 1994. - Вып. 3. - С. 377-383 [Электронный ресурс]. - URL: http://poetica.pro/journal/article.php?id=2435 (10.03.2019). DOI: 10.15393/ j9.art.1994.2435 (b)

5. Захаров В. Н. Русская литература и христианство // Проблемы исторической поэтики. - Петрозаводск: Изд-во ПетрГУ, 1994. - Вып. 3. C. 5-11 [Электронный ресурс]. — URL: http://poetica.pro/journal/article. php?id=2370 (10.03.2019). DOI: 10.15393/j9.art.1994.2370

6. Захаров В. Н. Почвенничество в русской литературе: метафора как идеологема // Проблемы исторической поэтики. - Петрозаводск: Изд-во ПетрГУ, 2012. - Вып. 10. - С. 14-24 [Электронный ресурс]. URL: http://poetica.pro/files/redaktor_pdf/1457946697.pdf (11.03.2019). DOI: $10.15393 /$ j9.art.2012.335

7. Зырянов О. В. Проблемно-методологическое поле современной этнопоэтики // Филологический класс. — 2019. — № 1 (55). - С. 8-15. 
8. Имихелова С. С. Образ-символ Ангары в прозе В. Г. Распутина // Творческая личность Валентина Распутина: живопись — чувство - мысль воображение - откровение: сб. науч. тр. / ред. И. И. Плеханова. Иркутск, 2015. - С. 267-276.

9. Ковтун Н. В. От «Прощания с Матёрой»к «Зоне затопления»: прогностический итог мифа В. Распутина о России // Валентин Распутин. Правда памяти: материалы Всерос. конфер., посвящ. 80-летию со дня рождения писателя. Иркутск, 28 сент. -2 окт. 2017 г. [отв. ред. В. Я. Иванова]. - Иркутск: Изд-во ИГУ, 2018. - С. 151-167.

10. Курбатов В. Каждый день сначала // Согласие. - 1991. - № 3. C. 215-221.

11. Курбатов В. Слово о В. Распутине на вручении премии А. Солженицына // Русская провинция. - 2000. - № 3. - С. 3-16.

12. Плеханова И. И. Идеи религиозно-нравственной философии в публицистике B. Распутина // Три века русской литературы: актуальные аспекты изучения: материалы Междунар. науч. конф., посвящен. 70-летию В. Г. Распутина (Иркутск, 15-16 марта 2007 года). - М.; Иркутск: Изд-во Иркут. ун-та, 2007. - Вып. 16: Мир и слово В. Распутина. - С. 308-333.

13. Распутин В. Вверх и вниз по течению / подгот. Л. Ронин // Природа и человек. - 1984. - № 11. - С. 32-34.

14. Распутин В. Г. Правая, левая где сторона // Наш современник. - 1989. — № 11. - С. $140-161$.

15. Распутин В. Г. Собр. соч.: в 3 т. - М.: Мол. гвардия, Вече, 1994. - Т. 3 : Сибирь, Сибирь...: очерки. Публицистика. -495 с.

16. Распутин В. В поисках берега: Повесть, очерки, статьи, выступления, эссе. - Иркутск: Издатель Сапронов, 2007. - 528 с.

17. Распутин В. У нас остается Россия: Очерки, эссе, статьи, выступления, беседы / сост. Т. И. Маршковой, предисл. В. Я. Курбатова; отв. ред. О. А. Платонов. - М.: Институт русской цивилизации, 2015. - 1200 с.

18. Рыбальченко Т. Л. Интуиция метафизического в прозе В. Распутина // Три века русской литературы: актуальные аспекты изучения: материалы Междунар. науч. конф., посвящен. 70-летию В. Г. Распутина (Иркутск, 15-16 марта 2007 года). - М.; Иркутск: Изд-во Иркут. ун-та, 2007. Вып. 16: Мир и слово В. Распутина. - С. 6-25.

19. Юрьева О. Ю. Этнотипология Ф. М. Достоевского в творчестве В. Г. Распутина // Три века русской литературы: актуальные аспекты изучения: материалы Междунар. науч. конф., посвящен. 70-летию В. Г. Распутина (Иркутск, 15-16 марта 2007 года). - М.; Иркутск: Изд-во Иркут. ун-та, 2007. - Вып. 16. Мир и слово В. Распутина. - С. 218-245.

20. Юрьева О. Ю. Русская идея Ф. М. Достоевского в творчестве В. Г. Распутина // Время и творчество Валентина Распутина: материалы Междунар. науч. конфер., посвящен. 75-летию со дня рождения Валентина Григорьевича Распутина. - Иркутск: Изд-во ИГУ, 2012. — С. 50-60. 
Olga Yu. Yureva

(Irkutsk, Russian Federation)

yuolyu@yandex.ru

\title{
The Chronotope of the Short Novel by V. Rasputin "Farewell to Matyora": Its Ethnopoetic Aspect
}

\begin{abstract}
The analysis of the artistic originality of V. G. Rasputin's novel "Farewell to Matyora" in the aspect of ethnopoetics reveals the ideas of "soilbound" tradition that became the basis of the aesthetics and axiology of his works. The spatial and temporal coordinates and loci of the story present the essence of the global conflict: eternity and modernity, culture and civilization, nature and man, the good and the evil. The chronotope of the story as an expression of the national picture of the world is presented in the conflict of the sacral and profane spaces in modern times. The sacral space and time are a synthesis of natural and human existence and has corresponding coordinate axes: the vertical one is the "Royal listven" and a church, the horizontal one is Angara and Matyora. The name of the island and the village has several semantic meanings: mother, mother-lend, mother-homeland, omnipotent, continent, spiritual continent, peasant Atlantean. Matyora as part of the national CosmoLogos is presented in a mythopoetic perspective as a living, intelligent, sensitive being, whose soul is the zoomorphic image of the "Owner of the island". The image of the Angara river as the most important horizontal sacred topos, organizing the chronotope of the story, incorporates the national archetypal connotations of the river-life, the river-road, the river-movement, acquires the strongly marked symbolic semantics of time, which is associated with the tragic collision of the onset of the "last times". The image of the "Royal listven", that organizes the vertical axis of the chronotope, incorporates the features of the archetype of the world tree and the national totem, symbolizing the indestructibility of eternal nature, the short-term "Pyrrhic victory" of man. The profane space is marked by images of the "lower", infernal world and a binary opposition "Owner/time-traveler". The poetics of the story has a strongly-pronounced Orthodox code, which gives to the finale of the story a truly apocalyptic sound. Keywords: Valentin Rasputin, ethnopoetics, national picture of the world, chronotope, space, time, archetype, image, sacred, profane
\end{abstract}

About the author: Yureva Olga Yu. - Doctor of Philology, Professor, Head of the Department of Philology and Methodology, Irkutsk State University (ul. Karla Marksa 1, Irkutsk, 664003, Russian Federation)

Received: March 25, 2019

Date of publication: June 28, 2019

For citation: Yureva O. Yu. The Chronotope of the Short Novel by V. Rasputin "Farewell to Matyora": Its Ethnopoetic Aspect. In: Problemy istoricheskoy poetiki [The Problems of Historical Poetics], 2019, vol. 17, no. 2, pp. 289-313. DOI: 10.15393/ j9.2019.6682 (In Russ.) 


\section{References}

1. Afanas'eva-Medvedeva G. V. Narodnoe slovo v rasskazakh i povestyakh Valentina Rasputina: slovar': $v 2$ tomakh [A Folk Word in the Stories and Short Novels of Valentin Rasputin: Dictionary: in 2 Vols]. Irkutsk, 2017, vol. 1.432 p. (In Russ.)

2. Galimova E. Sh. An Archetypal Image of the River in the Artistic World of Valentin Rasputin. In: Vremya i tvorchestvo Valentina Rasputina: materialy Mezhdunarodnoy nauchnoy konferentsii, posvyashchennoy 75-letiyu so dnya rozhdeniya Valentina Grigorevicha Rasputina [The Time and Works of Valentin Rasputin: Proceedings of International Scientific Conference Dedicated to the 75th Anniversary of the Birth of Valentin Rasputin]. Irkutsk, Irkutsk State University Publ., 2012, pp. 98-109. (In Russ.)

3. Esaulov I. A. The Category of Sobornost' in Russian Literature (Problem Statement). In: Problemy istoricheskoy poetiki [The Problems of Historical Poetics]. Petrozavodsk, PetrSU Publ., 1994, issue 3, pp. 31-60. Available at: http://poetica.pro/journal/article.php?id=2372 (accessed on March 10, 2019). DOI: 10.15393/j9.art.1994.2372 (In Russ.) (a)

4. Esaulov I. A. Axiology of Literary Criticism: Concept Establishment Experience. In: Problemy istoricheskoy poetiki [The Problems of Historical Poetics]. Petrozavodsk, PetrSU Publ., 1994, essue 3, pp. 377-383. Available at: http:// poetica.pro/journal/article.php?id=2435 (accessed on March 10, 2019). DOI: 10.15393/j9.art.1994.2435 (In Russ.) (b)

5. Zakharov V. N. Russian Literature and Christianity. In: Problemy istoricheskoy poetiki [The Problems of Historical Poetics]. Petrozavodsk, PetrSU Publ., 1994, issue 3, pp. 5-11. Available at: http://poetica.pro/journal/article.php?id=2370 (accessed on March 10, 2019). DOI: 10.15393/j9.art.1994.2370 (In Russ.)

6. Zakharov V. N. Pochvennichestvo in Russian Literature: the Metaphor as Ideologeme. In: Problemy istoricheskoy poetiki [The Problems of Historical Poetics]. Petrozavodsk, PetrSU Publ., 2012, issue 10, pp. 14-24. Available at: http://poetica.pro/files/redaktor_pdf/1457946697.pdf (accessed on March 11, 2019). DOI: 10.15393/j9.art.2012.335 (In Russ.)

7. Zyryanov O. V. A Problem-Methodological Field of Contemporary Ethnopoetics. In: Filologicheskiy klass, 2019, no. 1 (55), pp. 8-15. (In Russ.)

8. Imikhelova S. S. The Image-symbol of the Angara River in the Prose of V. Rasputin. In: Tvorcheskaya lichnost' Valentina Rasputina: zhivopis' chuvstvo - mysl' - voobrazhenie - otkrovenie [An Artistic Personality of Valentin Rasputin: Painting - Feeling - Thought - Imagination - Revelation]. Irkutsk, 2015, pp. 267-276. (In Russ.)

9. Kovtun N. V. From "Farewell to Matyora" to "Inundation Area": a Prognostic Result of the Myth of Rasputin about Russia. In: Valentin Rasputin. Pravda pamyati: materialy Vserossiyskoy konferentsii, posvyashchennoy 80-letiyu so dnya rozhdeniya pisatelya [V. Rasputin. The Truth of Memory: Proceedings of the all-Russian Conference Dedicated to the 80th Anniversary of the Writer's Birth]. Irkutsk, Irkutsk State University Publ., 2018, pp. 151-167. (In Russ.)

10. Kurbatov V. Every Day from the Beginning. In: Soglasie, 1991, no. 3, pp. 215-221. (In Russ.) 
11. Kurbatov V. A Word about Valentin Rasputin. In: Russkaya provintsiya, 2000, no. 3, pp. 3-16. (In Russ.)

12. Plekhanova I. I. The Ideas of Religious and Moral Philosophy in Political Essays of V. Rasputin. In: Tri veka russkoy literatury: aktual'nye aspekty izucheniya: materialy Mezhdunarodnoy nauchnoy konferentsii, posvyashchennoy 70-letiyu V. G. Rasputina [Three Centuries of Russian Literature: Topical Aspects of the Study: Proceedings of the International Scientific Conference Dedicated to the 70th Anniversary of V. G. Rasputin]. Moscow, Irkutsk, Irkutsk State University Publ., 2007, issue 16, pp. 308-333. (In Russ.)

13. Rasputin V. Upstream and Downstream. In: Priroda i chelovek, 1984, no. 11, pp. 32-34. (In Russ.)

14. Rasputin V. “The Right or Left-Side. Where is It?". In: Nash sovremennik, 1989, no. 11, pp. 140-161. (In Russ.)

15. Rasputin V. G. Sobranie sochineniy: $v 3$ tomakh [Collected Works: in 3 Vols]. Moscow, Molodaya Gvardiya Publ., Veche Publ., 1994, vol. 3. 495 p. (In Russ.)

16. Rasputin V. V poiskakh berega: Povest', ocherki, stat' $i$, vystupleniya, esse [In Search of the Shore: Novel, Sketches, Articles, Speeches, Essays]. Irkutsk, Izdatel' Sapronov Publ., 2007. 528 p. (In Russ.)

17. Rasputin V. U nas ostaetsya Rossiya: Ocherki, esse, stat'i, vystupleniya, besedy [We still Have Russia: Sketches, Essays, Articles, Speeches, and Discussions]. Moscow, the Institute of Russian Civilization Publ., 2015. 1200 p. (In Russ.)

18. Rybal'chenko T. L. Intuition of the Metaphysical in V. Rasputin's Prose. In: Tri veka russkoy literatury: aktual'nye aspekty izucheniya: materialy Mezhdunarodnoy nauchnoy konferentsii, posvyashchennoy 70-letiyu V. G. Rasputina [Three Centuries of Russian Literature: Topical Aspects of the Study: Proceedings of the International Scientific Conference Dedicated to the 70th Anniversary of V. G. Rasputin]. Moscow, Irkutsk, Irkutsk State University Publ., 2007, issue 16, pp. 6-25. (In Russ.)

19. Yur'eva O. Yu. The Etnotipology of Dostoevsky in the Works of V. Rasputin. In: Tri veka russkoy literatury: aktual'nye aspekty izucheniya: materialy Mezhdunarodnoy nauchnoy konferentsii, posvyashchennoy 70-letiyu $V$. G Rasputina [Three Centuries of Russian Literature: Topical Aspects of the Study: Proceedings of the International Scientific Conference Dedicated to the 70th Anniversary of V. G. Rasputin]. Moscow, Irkutsk, Irkutsk State University Publ., 2007, issue 16, pp. 218-245. (In Russ.)

20. Yur'eva O. Yu. A Russian Idea of F. M. Dostoevsky in the Works of V. G. Rasputin. In: Vremya i tvorchestvo Valentina Rasputina: materialy Mezhdunarodnoy nauchnoy konferentsii, posvyashchennoy 75-letiyu so dnya rozhdeniya Valentina Grigorevicha Rasputina [The Time and Works of Valentin Rasputin: Proceedings of the International Scientific Conference Dedicated to the 75th Anniversary of the Birth of Valentin Rasputin]. Irkutsk, Irkutsk State University Publ., 2012, pp. 50-60. (In Russ.) 